\title{
Foster Trailed-Incised: A GIS-Based Analysis of Caddo Ceramic Distribution
}

Duncan P. McKinnon

University of Central Arkansas

Follow this and additional works at: https://scholarworks.sfasu.edu/ita

Part of the American Material Culture Commons, Archaeological Anthropology Commons, Environmental Studies Commons, Other American Studies Commons, Other Arts and Humanities Commons, Other History of Art, Architecture, and Archaeology Commons, and the United States History Commons

Tell us how this article helped you.

This Article is brought to you for free and open access by the Center for Regional Heritage Research at SFA ScholarWorks. It has been accepted for inclusion in Index of Texas Archaeology: Open Access Gray Literature from the Lone Star State by an authorized editor of SFA ScholarWorks. For more information, please contact cdsscholarworks@sfasu.edu. 


\section{Foster Trailed-Incised: A GIS-Based Analysis of Caddo Ceramic Distribution}

Creative Commons License

(c) $)$ (i) @

This work is licensed under a Creative Commons Attribution-NonCommercial 4.0 International License 


\title{
FOSTER TRAILED-INCISED: A GIS-Based Analysis of CAddo Ceramic Distribution
}

\section{Duncan P. McKinnon}

\begin{abstract}
The use of a Geographic Information System (GIS) allows for dynamic visualizations in the analysis of spatial distributions and the modeling of data clusters and outliers. An on-going analysis of Foster TrailedIncised vessels found within the Caddo Homeland seeks to construct a distributional framework that can be applied and compared to additional Caddo ceramic types and site location attributes using a GIS database. Preliminary results show high frequencies of Foster Trailed-Incised vessels along the Ouachita and Red River drainages as well as along the Saline, Arkansas, and Little Missouri rivers in Arkansas. Additional possible varieties of Foster Trailed-Incised have been identified in Caddo, Ouachita and Morehouse parishes in Louisiana and at Caddo sites in northeast Texas. While a full analysis of the distribution of Foster Trailed-Incised vessels (and relationships with other Caddo vessel types) is far from complete, initial conclusions are presented in this article.
\end{abstract}

\section{Introduction}

The use of a Geographic Information System (GIS) allows for dynamic visualizations in the analysis of spatial distributions and the modeling of data clusters and outliers. Furthermore, a GIS offers the ability for the user to generate visual models of the spatial distribution of archaeological features that can be compared with environmental datasets, such as elevation, hydrology, or soil data (Wheatley and Gillings 2002).

This article presents some initial findings and thoughts from an on-going GIS analysis of Caddo ceramic vessels recorded within the Caddo Homeland. This specific analysis uses a GIS to visualize the distribution of known Foster Trailed-Incised vessels, along with selected additional vessels that are similar in form and design to the Foster Trailed-Incised type. This analysis provides a distributional framework that can be applied and compared to additional Caddo ceramic types and site location attributes across the Caddo landscape. The majority of vessels discussed in this analysis is referred to as Foster Trailed-Incised and is included as a collective based on similarities in form and design, as discussed below.

The GIS database discussed here was created using Foster Trailed-Incised ceramic vessels primarily gathered from an "analog database" of data cards containing vessel photographs, site provenience (where known), and available attributes that have been documented by several contributors (mentioned in the acknowledgments) and are from collections throughout southwestern Arkansas. The photo cards were compiled and organized by Dr. Frank F. Schambach during his tenure as Station Archeologist at the Arkansas Archeological Survey station in Magnolia, Arkansas. Archaeological literature and site reports were also perused in search of additional recordings of Foster Trailed-Incised vessels found throughout the Caddo Homeland (see Brown 1996; Crook and Perttula 2008; Early 1988, 1993a; Hart 1982; Hemmings 1982; House 1991; Jackson et al. 2000; Kelley 1997; Kelley and Cox 1998; Kidder 1988; Krieger 1946; Lynott 1975a, 1975b; 
Moore 1912; Moorehead 1931; Perino 1994, 1995; Perttula 2005, 2006; Perttula et al. 2009a, 2009b, 2009c, 2009d; Perttula and Nelson 2009; Rohbaugh 1982; Sundermeyer et al. 2008; Schambach 1981; Schambach et al. 1982; Schambach and Miller 1984; Suhm et al. 1954; Suhm and Jelks 1962; Trubowitz et al. 1982a; Walters 1997; Webb 1959; Webb and Dodd 1941; Weinstein et al. 2003).

A total of 360 whole or mostly whole vessels have been identified that contain various criteria (discussed below) to be considered Foster Trailed-Incised in type and variety (Figure 1a-b). Of the 360 vessels, 284 contain known site provenience (critical for a distribution analysis) and are included in this analysis. The 76 without site provenience are not included. Various sherds identified in the literature as possibly part of Foster TrailedIncised vessels are also excluded because of known ambiguities associated with the assignment of decorated Caddo sherds to a type-variety system (see Early 1988, 1993a; Kelley 1997; Schambach 1981; Schambach and Miller 1984 for discussions on the Collegiate Classification System used in Arkansas and Louisiana ceramic analysis).

Attribute data were gleaned from notes associated with the Magnolia "analog database" and from tables within publications. At this time, none of the vessels have been analyzed (by me) apart from a review of the numerous images that have been gathered, scanned, and compiled. As a result, some data attributes about vessels are not included in this analysis and will require further exploration by examining the actual vessels (where available) and documentation forms (many of which are on file at various museums) as this project continues. Nonetheless, this preliminary review using the data that has been collected thus far sheds light on the efficacy of a GIS-based distributional analysis as it pertains to Caddo ceramic vessels.
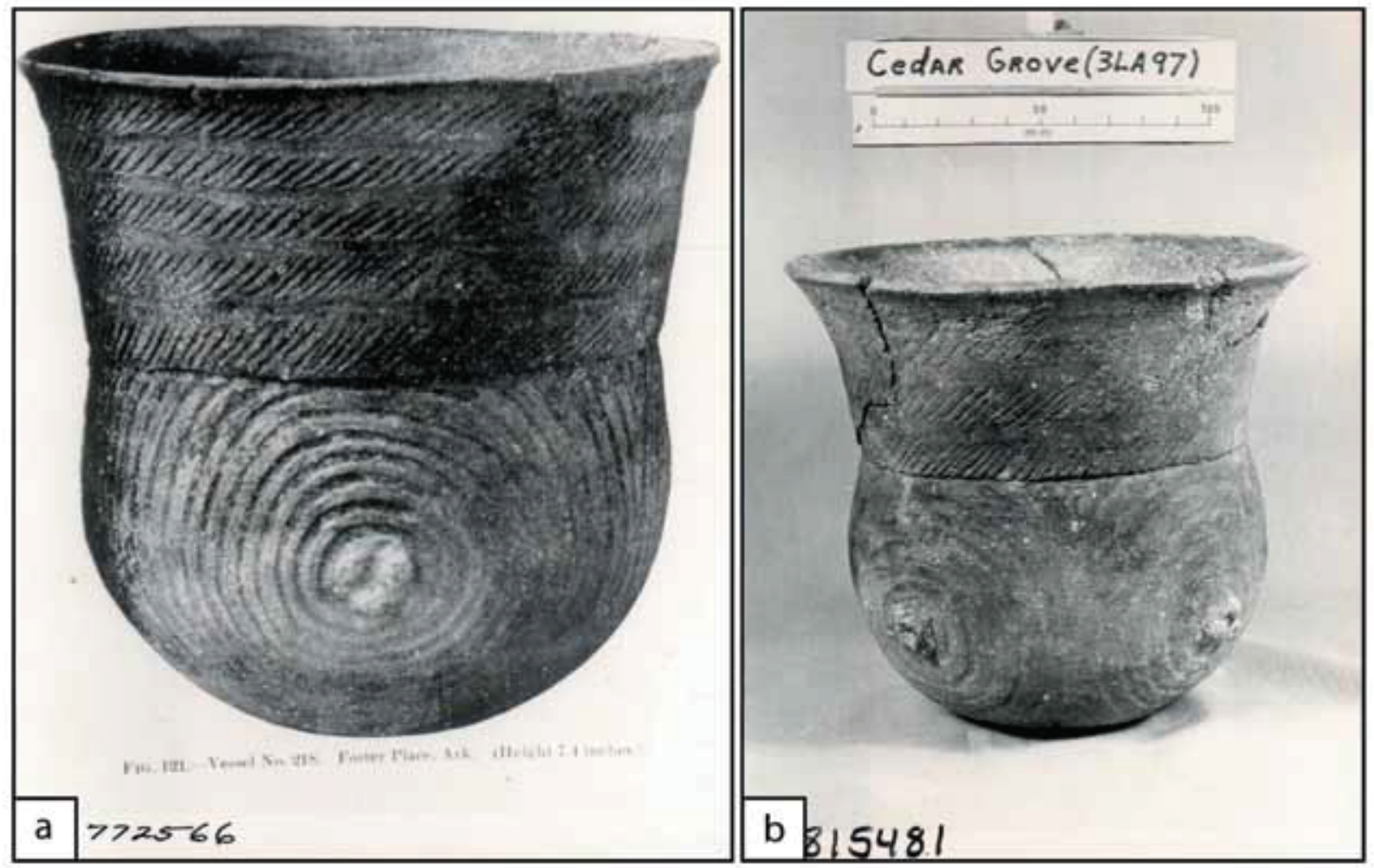

Figure 1. Examples of Foster Trailed-Incised vessels. (a) Foster Place site (3LA27) (AAS Neg. \#772566; Moore 1912: Figure 121). (b) Cedar Grove site (3LA97) (AAS Neg. \#815481; Schambach and Miller 1984: Figure 11-21a). 


\section{Foster Trailed-Incised: Temper, Form, and Treatment}

Foster Trailed-Incised vessels are considered a Late Caddo (A.D. 1400-1680) type predominately associated with Caddo occupations in the Ouachita and Red River drainages (Suhm et al. 1954; Suhm and Jelks 1962) with additional distributions along the Saline, Arkansas, and Little Missouri rivers. Additionally, varieties of Foster Trailed-Incised have been identified in Ouachita and Morehouse parishes in northeast Louisiana (Kidder 1988) and at Caddo sites in northeast Texas (Crook and Perttula 2008; Perttula 2005; Sundermeyer et al. 2008; Walters 1997).

\section{Vessel Temper}

Webb and Dodd (1941) are the first to describe construction and decorative criteria associated with Foster Trailed-Incised vessels, although several others have elaborated (or contested) vessel characteristics (see Krieger 1946; Suhm et al. 1954; Suhm and Jelks 1962; Webb 1959; Schambach and Miller 1984; Early 1988, 1993a; Kelley 1997). Webb and Dodd describe vessel construction as clay tempered with occasional shell. Webb (1959:131) further elaborates by stating that temper is "preponderantly clay-tempered" with "occasional sand or tuff, presumably accidental" and shell or bone temper is considered rare. Krieger (1946), Suhm et al. (1954) and Suhm and Jelks (1962) classify Foster Trailed-Incised vessels as having clay grit or finely pulverized shell temper. A single vessel located by Early (1988:74) at the Standridge site (3MN53) is described as containing "liberal quantities of finely pulverized shell".

Variations in the dominant temper used are likely related to the distribution of localized resources and regional adherence to cultural "rules" associated with vessel construction. This is not to imply an absence of a resource, but rather the suggestion of regional approaches in the utilization of particular resources. Of the Foster Trailed-Incised vessel images that are included in the database thus far $(n=284)$, temper is recorded in $22.89 \%(n=65)$ of the vessels. Of these, shell temper occurs in $75.38 \%(n=49)$ and grog temper in $24.62 \%$ $(n=16)$.

Vessel Form

Regarding vessel form, Webb and Dodd (1941) include vases, conical bowls, modified globular pots and cups, modified jars, and bottles as possible vessel forms. Suhm et al. (1954) and Suhm and Jelks (1962) include only small jars or globular bowls with a base that is "usually convex so vessel does not stand up well; sometimes flat." Webb (1959:132) identifies the lip as rounded and unmodified with a base that is described as "usually flat." Schambach and Miller (1984:121) consider an evolution of vessel forms that range from a tall flared-rim to possible short-rim jars. Of the Foster Trailed-Incised vessel images that have been reviewed ( $\mathrm{n}=284$ ), and using simplified categories of tall-rim and short-rim jars, tall rims occur in $80.63 \%(\mathrm{n}=229)$, and short-rimmed jars occur in $13.38 \%(n=38)$ of the vessels. Approximately $6.0 \%(n=17)$ either have no rims or rims have been broken and are missing.

\section{Vessel Treatment}

Webb and Dodd (1941:96) describe decorative treatment as trailed and heavily incised decorations with deep U-shaped incisions and shallower, wider trailed lines on the vessel body that form concentric circles. The concentric circle motif is the principal body design associated with this type. Small "teat-like" nodes in groups of three are located in the center of concentric circles on some vessels. Single nodes, or non-decorated centers are also well documented. Rims often contain lightly incised lines or punctates on tall rims. Suhm et al. (1954:272) and Suhm and Jelks (1962:43) describe the decorative treatment as containing "incising, trailing (incising with a broad, round-tipped tool), punctating, and appliqué." 
At the Cedar Grove site (3LA97) along the Red River in southwest Arkansas, Schambach and Miller (1984:121 and Figure 11-10) present an evolution of Foster Trailed-Incised vessels that are divided into seven varieties based on differences in design and decorative treatment. Those varieties are Foster, Dobson, Red Lake, Dixon, Moore, Shaw, and Finley.

The Cedar Grove seriation begins with Foster Trailed-Incised var. Foster, which contains a concentric circle motif on the body and multiple bands of zoned diagonal lines on a tall rim (see Figure 1b). This design motif evolves through a series of varieties, each containing variations of the motifs found on the var. Foster. The Foster Trailed-Incised seriation ends with varieties Shaw and Finley, each containing vertically oriented interlocking scroll designs on the body with unzoned punctates on the tall rim of var. Shaw and a single row of diagonal incised lines on the short rim of var. Finley. Although a candidate for "one of the best, and most sensitive time indicators in the Great Bend region" (Schambach and Miller 1984:121), the Cedar Grove Foster Trailed-Incised seriation has yet to be tested at other sites or regions.

\section{Similar Vessel Types}

Several Caddo vessels are similar in either form or design, which adds a significant level of complexity when attempting to assign a particular type in the standard type-variety typology. Similar forms and designs likely represent a cultural "over-lap" between regional groups of populations and the implementation of various characteristics in vessel construction and design. By including vessel types that likely represent a cultural "overlap" in a GIS database, it is hoped that areas of differential vessel type densities can be discerned, clusters in distributions recognized, and spatial patterns analyzed.

Some types similar in either form or design treatment to Foster Trailed-Incised include Cowhide Stamped (Suhm et al. 1954: Plate 13; Suhm and Jelks 1962: Plate 15), Keno Trailed (Suhm et al. 1954: Plate 39; Suhm and Jelks 1962: Plate 44), Killough Pinched (Suhm et al. 1954: Plate 41; Suhm and Jelks: Plate 46), and Military Road Incised (Suhm et al. 1954: Plate 48; Suhm and Jelks 1962: Plate 54). As part of this preliminary analysis of Foster Trailed-Incised, a small representation of the most similar Cowhide Stamped $(\mathrm{n}=36)$ and Keno Trailed ( $\mathrm{n}=7$, notably var. Scotts Lake) vessel type varieties are included.

Some Cowhide Stamped vessel forms are similar to Foster Trailed-Incised (Figure 2). Some body decorations on Cowhide Stamped vessels have similar (if not identical) concentric circle designs as those on Foster Trailed-Incised vessels. For example, two short rim vessels from sites (3HS100 and 3HS33) in Hot Spring County contain concentric design similar to Foster Trailed-Incised (Figure 2a-b). A Cowhide Stamped vessel, from the Battle Mound site (3LA1), demonstrates the similar concentric circle design motif on the body but with scroll bands of stamping rather than incising and containing a short rim (Figure 2c). Additionally, several Cowhide Stamped vessels documented at the Belcher Site (16CD13) along the Red River in northwest Louisiana have concentric circle body motifs similar to Foster Trailed-Incised vessels (Webb 1959:Figure 109).

Keno Trailed vessels exhibit a similar trailing scroll design on the body with "combinations of straight and curved parallel lines fitted close together to cover nearly the entire body" (Suhm et al. 1954:310; Suhm and Jelks 1964:87). However, the vessel shape is more globular with only a short out-flaring rim. Central nodes are often absent. Two Keno Trailed var. Scotts Lake (Schambach and Miller 1984:123) vessels from the Battle Mound site (3LA1) (Moore 1912:Figure 61; Perttula et al. 2009:Figure 14d) nicely demonstrate the similarity in the scrolling design motif on the body (Figure 3a-b). 

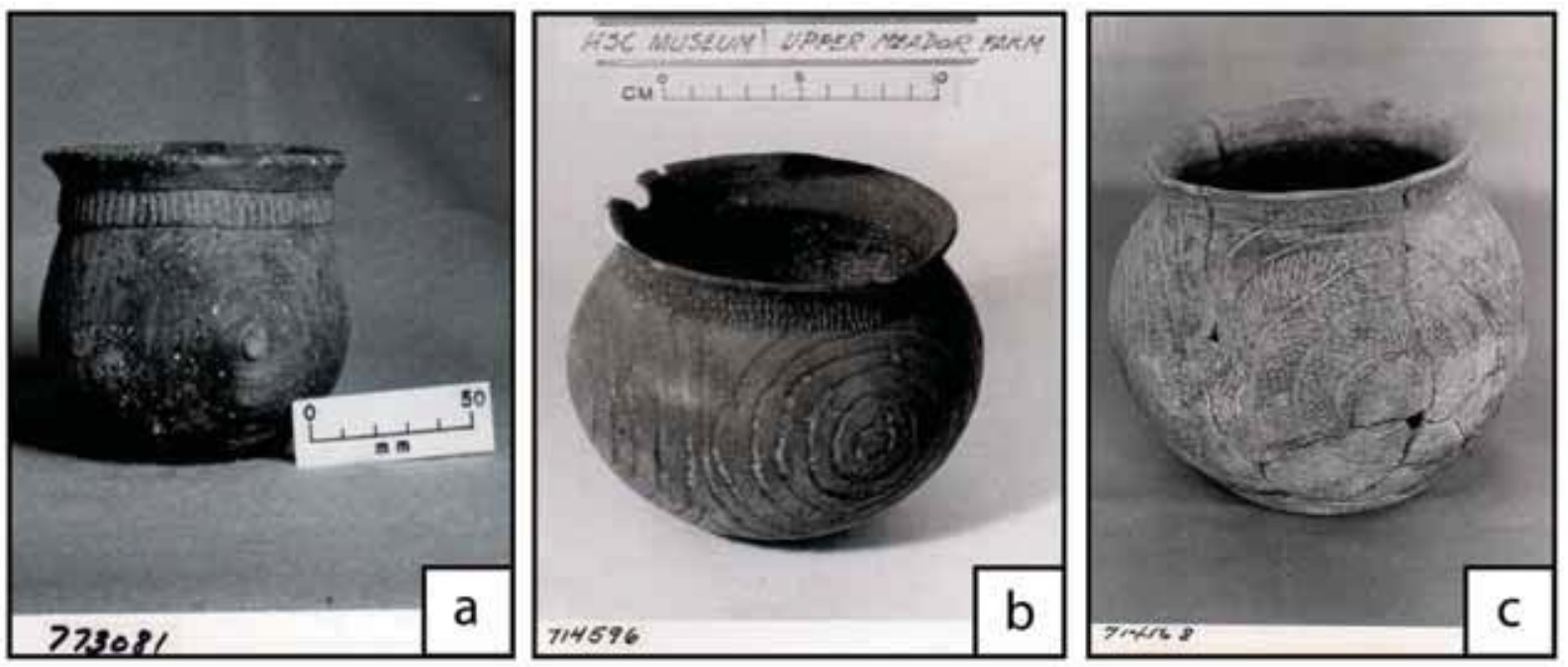

Figure 2. Examples of Cowhide Stamped vessels. (a) McDonald Cole Field (3HS100) (AAS Neg. \#773081). (b) Upper Meador Farm (3HS33) (AAS Neg. \#714596). (c) Battle Mound site (3LA1) (AAS Neg. \#714168).
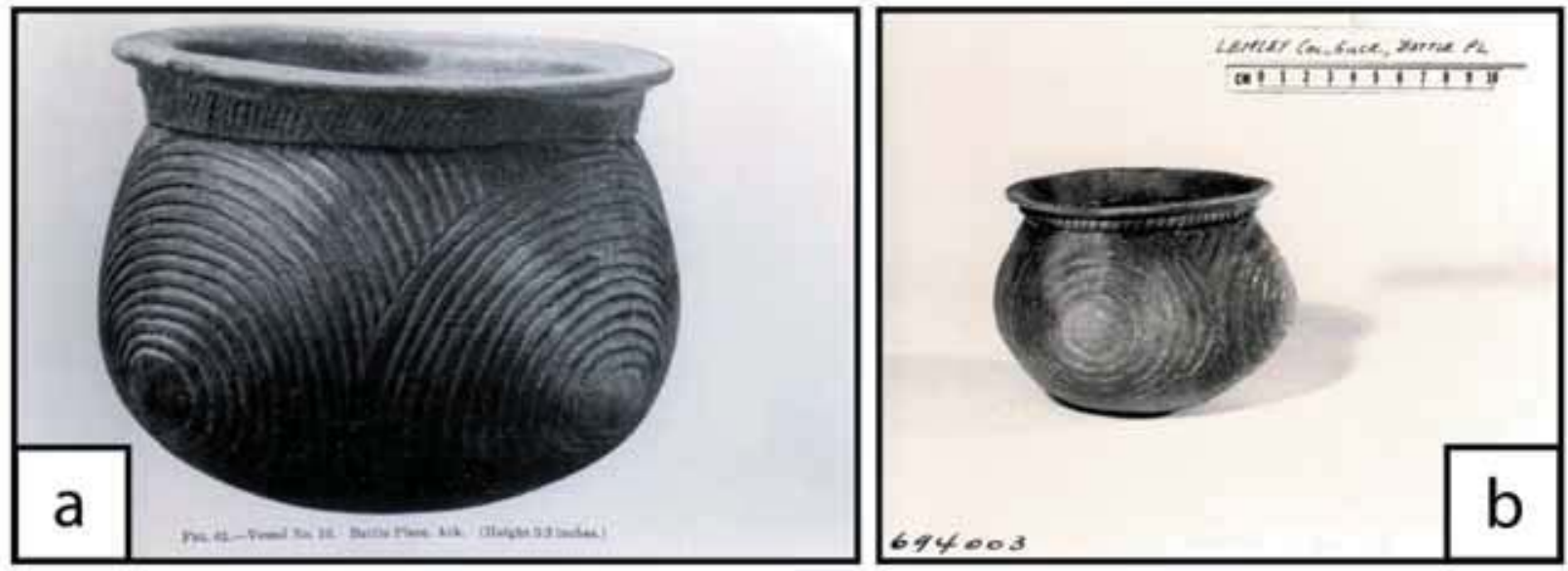

Figure 3. Examples of Keno Trailed vessels. (a) Battle Mound site (3LA1) (Moore 1912: Figure 61). (b) Battle Mound site (3LA1) (AAS Neg. \#694003).

\section{Foster Trailed-Incised Distribution in a GIS}

The current database contains a total of 284 whole and mostly whole vessels that meet some if not all of the criteria (largely based on form and design) to be considered a Foster Trailed-Incised vessel and variety of the type. The vessels were found at 82 known sites and spread across 22 counties in Arkansas and Texas and three parishes in Louisiana (Figure 4).

Foster Trailed-Incised vessels have yet to be identified at sites in Oklahoma, although Moorehead (1931:43, Figure 20) illustrates a vessel that is similar in design and form to Foster Trailed-Incised vessels. The vessel is listed in the caption as being from "eastern Oklahoma". Since specific site provenience is not known, it is not included in this analysis. 


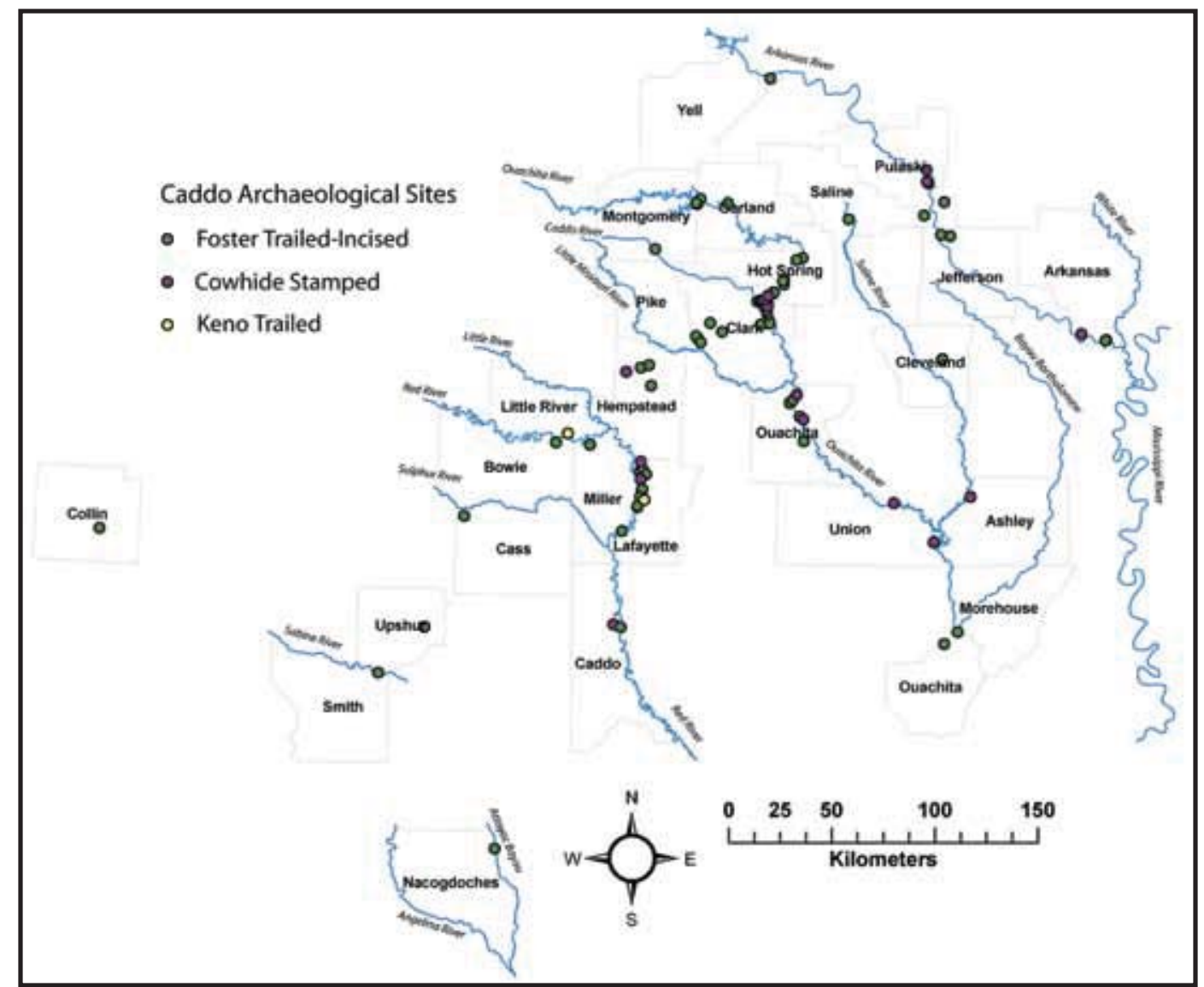

Figure 4. A distribution map of Foster Trailed-Incised, select Cowhide Stamped, and select Keno Trailed vessels in Arkansas, Louisiana, and Texas.

Arkansas has the largest representation in Arkansas $(n=2)$, Clark $(n=50)$, Cleveland $(n=2)$, Garland $(n=10)$, Hempstead $(n=10)$, Hot Springs $(n=46)$, Jefferson $(n=9)$, Lafayette $(n=84)$, Little Rock $(n=2)$, Miller $(n=3)$, Montgomery $(n=5)$, Ouachita $(n=16)$, Pike $(n=1)$, Pulaski $(n=18)$, Saline $(n=3)$, and Yell $(n=1)$ counties. In Texas, sites in Bowie $(n=1)$, Collin $(n=1)$, Cass $(n=1)$, Nacogdoches $(n=1)$, Smith $(n=1)$, and Upshur $(n=1)$ counties are represented. In Louisiana, sites in Caddo $(n=12)$, Ouachita $(n=3)$, and Morehouse $(n=1)$ parishes are represented.

Additionally, and a product for further analysis, this general distribution shows occurrences of Cowhide Stamped vessels primarily situated along of the Ouachita River (with some examples along the Red River) and as far north as the Arkansas River, whereas Keno Trailed var. Scotts Lake vessels are situated south of the Ouachita River primarily on the Red River (see Figure 4). Current data gathering shows sites with Cowhide Stamped (those most closely resembling Foster Trailed-Incised in form and design) are situated in Arkansas $(\mathrm{n}=1)$, Ashley $(\mathrm{n}=1)$, Clark $(\mathrm{n}=2)$, Hempstead $(\mathrm{n}=1)$, Hot Spring $(\mathrm{n}=3)$, Lafayette $(\mathrm{n}=6)$, Ouachita $(\mathrm{n}=2)$, Pulaski $(\mathrm{n}=4)$, and Union $(\mathrm{n}=3)$ counties in Arkansas and Caddo Parish $(\mathrm{n}=13)$ in Louisiana. Keno Trailed var. Scotts Lake vessels (those most closely resembling Foster Trailed-Incised in form and design) are situated in Lafayette $(\mathrm{n}=6)$ and Little River $(\mathrm{n}=1)$ counties in Arkansas.

The Universal Transverse Mercator (UTM) coordinates for each site were acquired from the Arkansas Archeological Survey AMASDA site database, the Texas Historical Commission Historic Sites Atlas, and the Louisiana Division of Archaeology Cultural Resources Map. Site databases in Oklahoma were not consulted, given the lack of Foster Trailed-Incised vessels identified in the literature directly associated with Oklahoma sites. 


\section{GIS Distribution: Quantity, Temper and Form}

While preliminary, several distribution maps have been created using attributes associated with quantity, temper, and form, thus allowing for further questions and subsequent analyses to be derived.

\section{Quantity}

A distribution map of quantities of vessels at each site (taking into consideration potential biases in site selection and collection methods) shows clustering of Foster Trailed-Incised vessels along the Red, Ouachita, and Arkansas River drainages (Figure 5). Vessels, in lesser quantities (or lesser discovered quantities), are also distributed along the Caddo and Little Missouri rivers in Arkansas, in Ouachita and Morehouse parishes in northeast Louisiana along Bayou Bartholomew, and in northeast Texas.

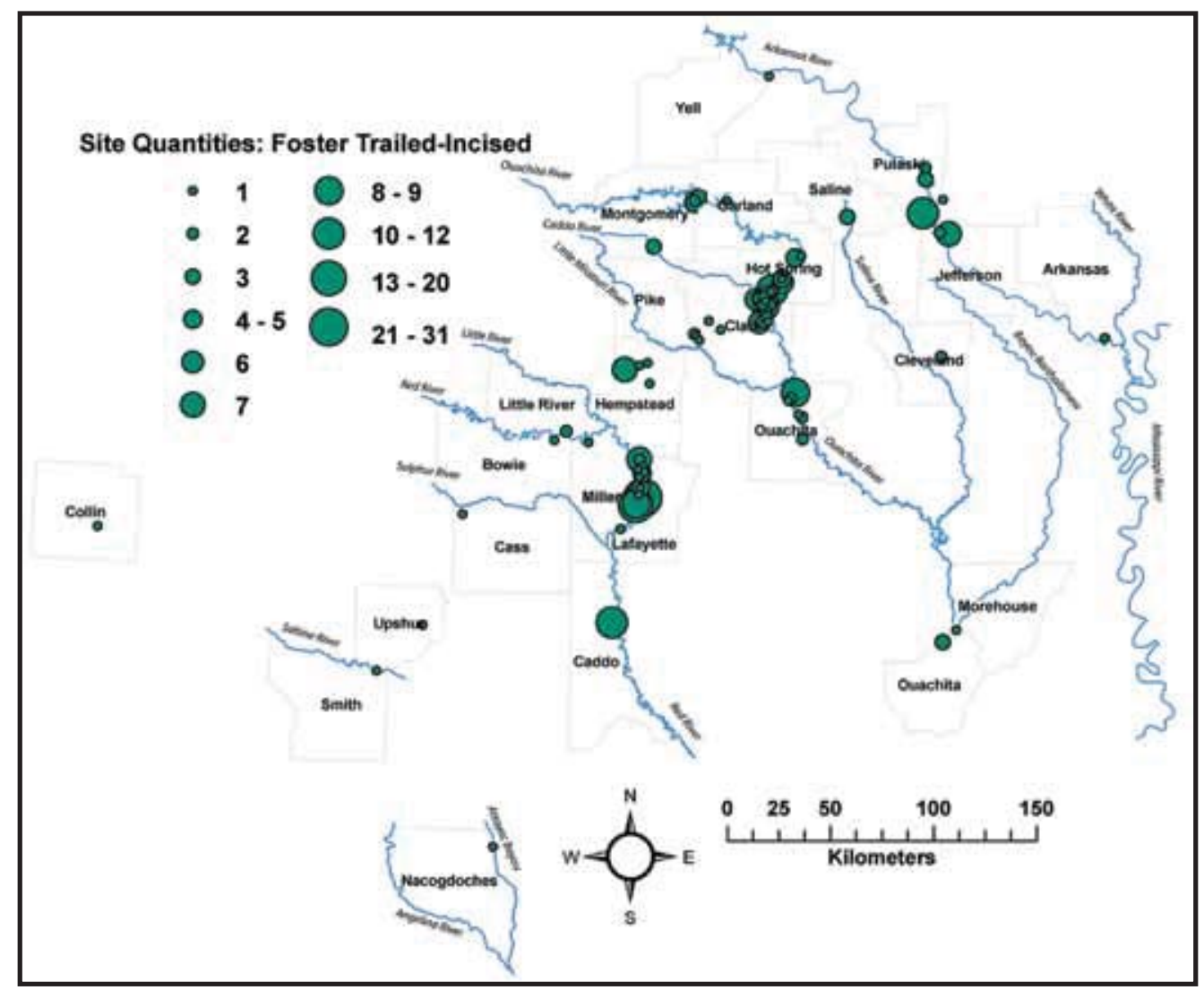

Figure 5. A distribution map of quantities of Foster Trailed-Incised vessels at individual sites.

The largest site quantity occurs at Battle Mound (3LA1), a heavily collected Middle and Late Caddo mound site on the Red River, with 31 Foster Trailed-Incised vessels. Second, with 20 vessels, is the Lester Place (3LA38), a later Caddo non-mound site, inundated by the natural processes of the Red River meander and likely a part of a series of farmsteads. The Kuykendall Brake site (3PU111), a multi-component site located on a former channel of the Arkansas River in Pulaski County, contains 12 Foster Trailed-Incised vessels (the most frequently occurring vessel type recorded at that site). The Belcher site (16CD13) along the Red River in northwest Louisiana also contains 12 Foster Trailed-Incised vessels. Next on the list is the Bob Fisher Mound (3HS22) in Hot Spring County, Arkansas with 11 recorded Foster Trailed-Incised vessels. Additional sites with high Foster Trailed-Incised occurrences are situated along the Ouachita River in Hot Spring and Clark counties and along the Red River in Lafayette and Miller counties. Vessel numbers at these sites average between 6 and 8 vessels. While this distribution has inherent biases based on a number of collection factors, three areas of higher occurrences can be identified along the Red, Ouachita, and Arkansas Rivers (see Figure 5). 


\section{Temper}

Although temper is not yet a part of the documentation of the many of the Foster Trailed-Incised vessels included in this database (being in various public and private collections and yet to be reviewed by the author), a preliminary distribution map does reveal some insights worthy of further exploration (Figure 6). As already mentioned, shell temper is the most prevalent temper where temper has been recorded or noted ( $\mathrm{n}=65$; $22.89 \%$ ). A distribution map of temper reveals that shell temper is fairly equally distributed across the study area with clusters in the Red, Ouachita, and Arkansas River drainages. Interestingly, grog temper is primarily located along the Red River drainage and at sites further west into east Texas.

This distribution alludes to a connection between the type of temper used and the distribution of localized clay and temper resources as well as regional adherence to cultural "rules" associated with vessel construction. It also offers an avenue of analysis as correlations are explored between temper type and ecological and geological data layers.

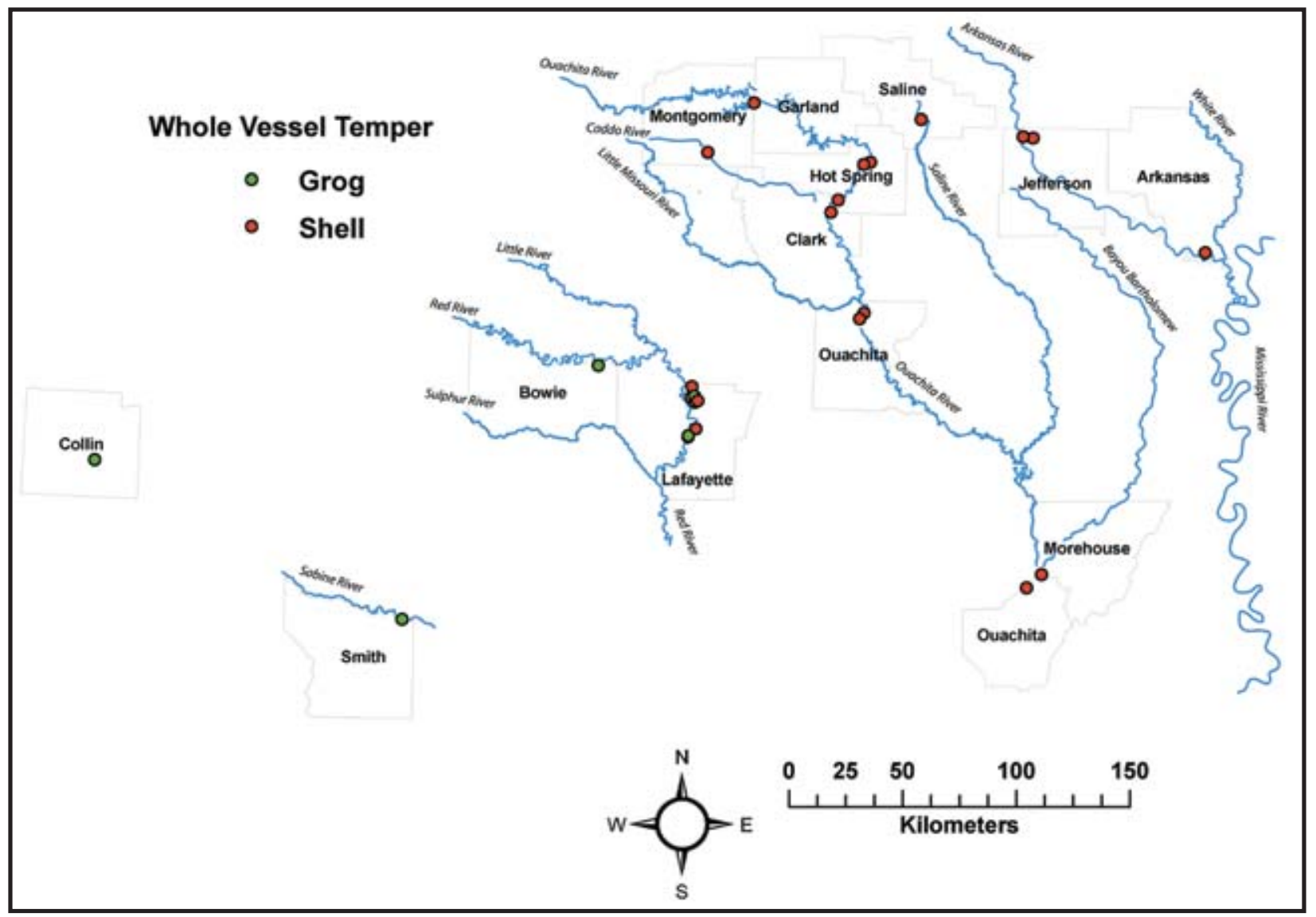

Figure 6. A distribution map of whole vessel temper associated with Foster Trailed-Incised vessels. 
Form

Experimenting with distribution of vessel form, three generalized categories of tall, short, or none/ missing rim were assigned to the Foster Trailed-Incised vessels in the database. The resulting distribution map shows the different rim types spread out across the entire study area (Figure 7). More categories of rim type (that is, more precise observations and measurements of rim characteristics) or other vessel form attributes are likely to reveal more interpretable results. In spite of this, two locations that show interesting distribution clusters to be further explored are along the Arkansas River in Pulaski and Jefferson counties and along the Ouachita River in Hot Spring and Clark counties. Tall rim vessels are mostly absent in the area along the Arkansas River, whereas short rim vessels are mostly absent along the Ouachita River.

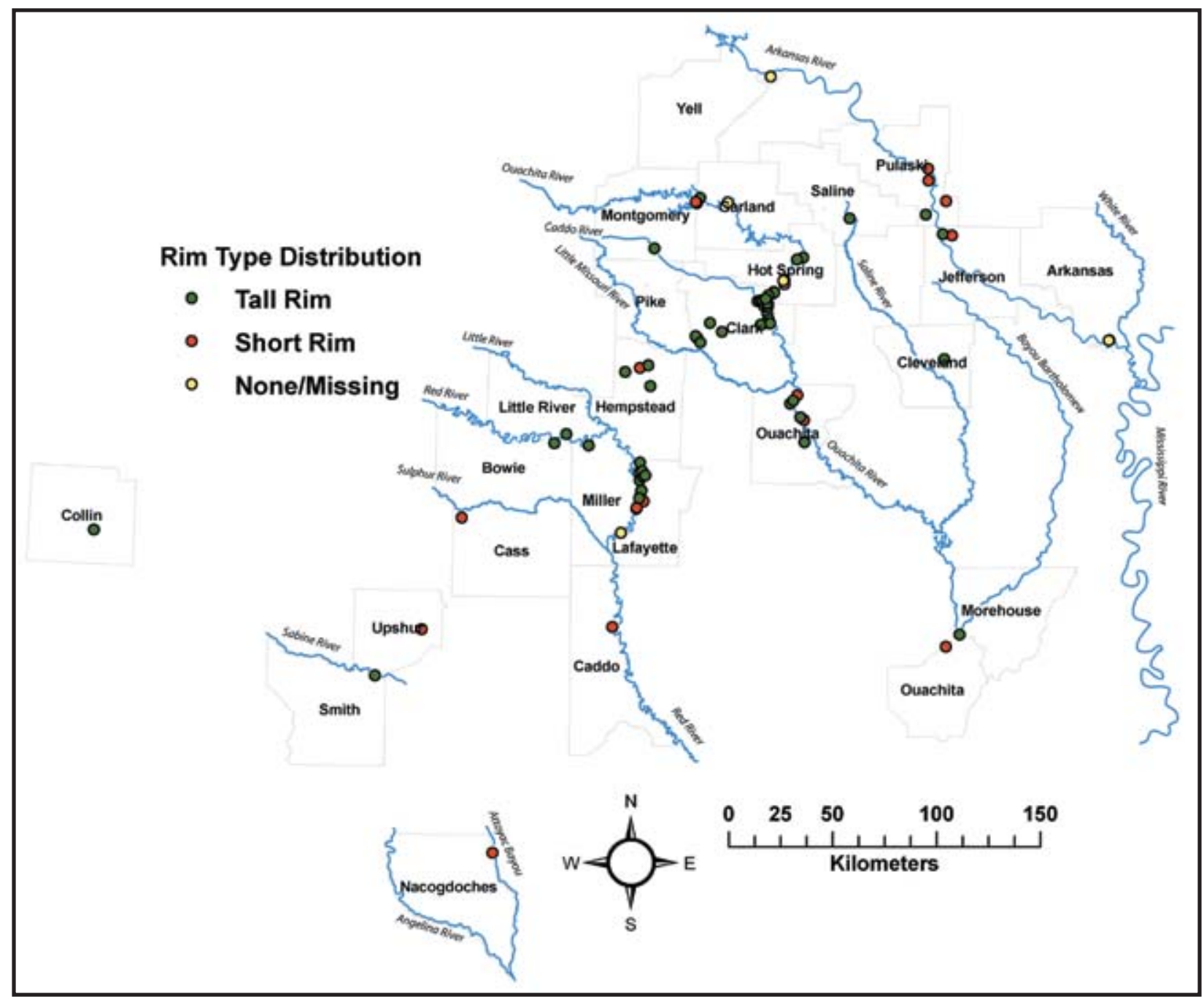

Figure 7. A distribution map of rim type associated with Foster Trailed-Incised vessels. 


\section{Distance Loci Analysis}

A simple Standard Distance algorithm reveals that the locus of the Foster Trailed-Incised vessel distribution is situated in the Ouachita River area around Clark and Hot Spring counties in Arkansas (Figure 8). A 2-standard deviation distance analysis reveals a distributional radial distance of approximately $150 \mathrm{~km}$ that includes most of the sites along the Ouachita, Red, and Arkansas River areas. Of course, with any statistical analysis more data (more identified Foster Trailed-Incised vessels) will allow for additional confidence in the results. However, this preliminary analysis reveals a few sites along the southern portion of Bayou Bartholomew in Louisiana (although on the border), in north-central and east Texas, and along the southern most portions of the Arkansas River in Arkansas County that are not within the 2-standard deviation distance and are considered, for this analysis, as outliers.

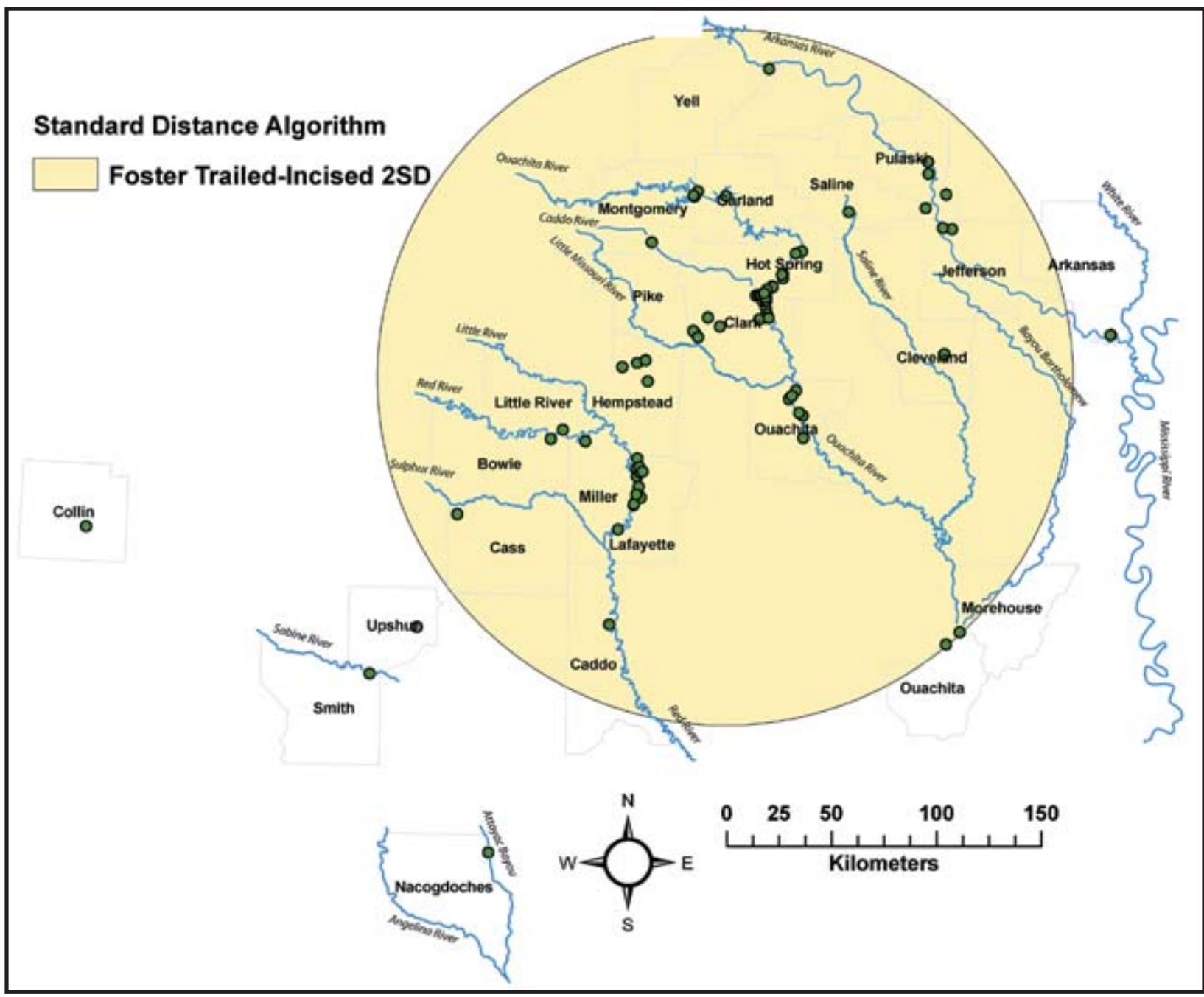

Figure 8. A 2-standard deviation distance analysis of the total distribution of Foster Trailed-Incised vessels.

\section{Distance Outliers}

Examples of outliers are found at a few sites, including the Joe Little, Henry Williams (41UR318), and Langford (41SM197) sites in east Texas, the Sister Grove Creek site (41COL36) in north-central Texas, the Wallace site (3AR25) in eastern Arkansas, and the Glendora (160U32) and Keno (160U31) sites in northeast Louisiana (see Figure 8). 
Joe Little site

The Joe Little site is located along the Attoyac Bayou in northeast Nacogdoches County, Texas. Dr. Herndon Burr excavated minimally in the 1960s at the site and a single Foster Trailed-Incised vessel was located (Tom Middlebrook, personal communication 2009). Although Dr. Tom Middlebook has searched extensively for the site location, the site has not been identified and recorded. Consensus is that the site was likely destroyed and put in the fill of the nearby Farm to Market road.

The vessel from the Joe Little site is globular in form with a short out-flaring rim (Figure 9a). The body is decorated with incised scrolling designs and appliqué nodes are present. The rim design consists of annular punctuates. Following the seriation outlined by Schambach and Miller (1984:121), the vessel most resembles the Late Caddo var. Moore or var. Shaw, but does contain differences in body incised scrolling designs.

Interestingly, the vessel from the Joe Little site resembles a vessel from the Lymon Moore site (34LF31), in the vicinity of Spiro in the Arkansas Valley, which is classified as Braden Punctated (Rohrbaugh 1982:461, Figure 20). The body design on the Joe Little vessel is also similar to a vessel found at the Los Adaes site (16NA16) near Natchitoches, Louisiana that is classified as Emory Punctated-Incised (Gregory, 1973:121, Figure 13f).
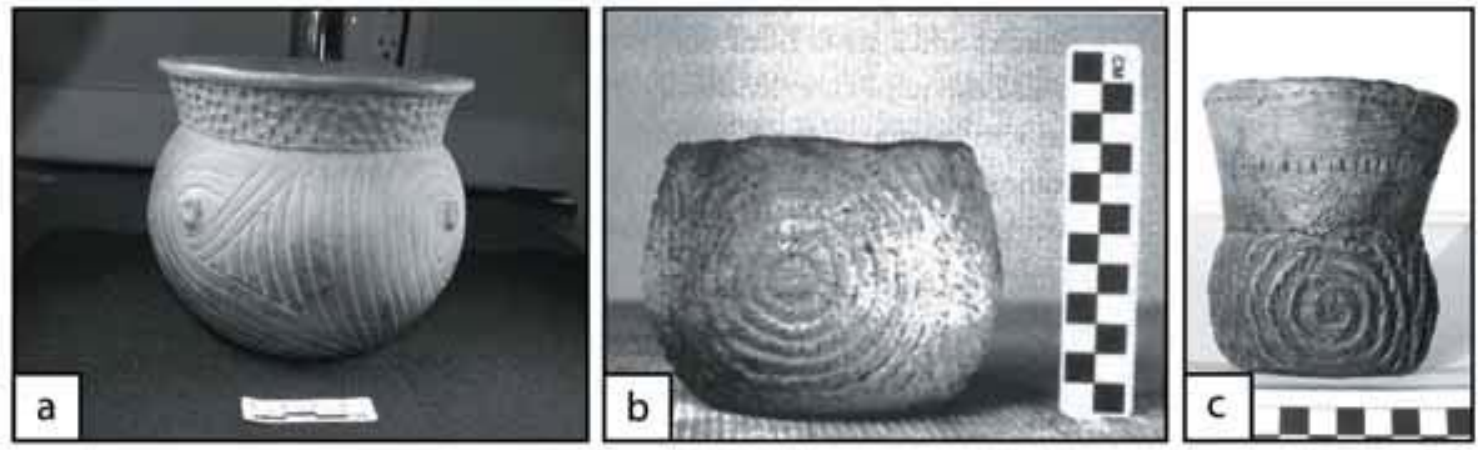

Figure 9. Outlier vessels containing Foster Trailed-Incised characteristics. (a) Joe Little site (image courtesy of Tom Middlebrook) (b) Henry Williams site (41UR318) (Perttula 2006) (c) Langford site ( 41SM197) (Walters 1997).

Henry Williams site (41UR318)

Little is known about the Henry Williams site apart from it being one of many excavated by Buddy Jones in the 1950s and 1960s in Upshur County, Texas (Perttula 2006:2). The site likely contains Middle to Late Caddo (A.D. 1200-1680) occupations, based on the presence of a Pease Brushed-Incised vessel.

A pinched bowl from the Henry Williams site contains a design motif on the body similar to those that represent Foster Trailed-Incised (Figure 9b). Additionally, the vessel is globular in form but without a rim. The design on the body is comprised of concentric circles and is included in this distribution analysis based simply on design similarities to Foster Trailed-Incised. Although pinching is not an essential criterion of Foster TrailedIncised varieties found at sites further east of the Henry Williams site, the pinched decoration technique is fairly typical in east Texas and slightly resembles Harleton Appliquéd vessels (Suhm et al. 1954: Plate 28; Suhm and Jelks 1962: Plate 33) or even Killough Pinched (Suhm et al. 1954: 41; Suhm and Jelks 1962: Plate 46).

\section{Langford site (41SM197)}

The Langford Site in Smith County, Texas, was excavated by the Walters family in 1960 and contained a house, several middens, and a small cemetery. The site is considered a single component Middle Caddo (A.D. 1200-1400) occupation site based on "several red slipped bowls, a brushed-punctated vessel, the occurrence of engraved ladders and panels on bottles and bowls, and a vessel with engraved snake designs" (Walters 1997:39). 
At the site, an interesting vessel that resembles Foster Trailed-Incised in both form and design has been recorded (Figure 9c). The body has broad concentric circles and two rows of punctations on the rim divide sets of narrow and interlocking incised lines, similar to Foster Trailed-Incised. However, the design treatment on the body is pinching and more similar to vessels classified as Killough Pinched (Suhm et al.1954: Plate 41; Suhm and Jelks 1962: Plate 46). The vessel is unlike those located at sites within the Red River valley (see Schambach and Miller 1984) or the Ouachita River valley (see Early 1993a).

Walters (1997:38) suggests this vessel might be an earlier variety of Foster Trailed-Incised or a local undefined variety. In contrast, Perttula et al. (2009) describe additional details of the vessel and assign it to the type Washington Square Paneled (Hart 1982) based on the horizontal interlocking scrolls of punctuates on the rim and the consideration that the Langford site has been identified as Middle Caddo (A.D. 1200-1400) in age.

\section{Sister Grove Creek (41COL36)}

By far the most interesting Foster Trailed-Incised outlier is the vessel found at the Sister Grove Creek site in Collin County, Texas (Crook and Perttula 2008). The Sister Grove Creek site is a Late Prehistoric site located on the East Fork of the Trinity River in north-central Texas where an 85\% complete reconstructed Foster Trailed-Incised vessel was identified (Figure 10a). The Foster Trailed-Incised vessel was located after a strong rainstorm and in close proximity to a previously identified large pit feature (see Lynott 1975a, 1975b). The vessel represents the first known occurrence of this vessel type along the East Fork of the Trinity River (Crook and Perttula 2008). The form is globular with an out-flaring rim. The rim design contains four horizontal panels of diagonal lines. The designs on the body are trailed concentric semi-circles, although it is missing the appliqué nodes.

The lack of other Foster Trailed-Incised vessels in the East Fork of the Trinity River region implies that this vessel was likely traded from a Caddo group along the Red River in southwestern Arkansas. Radiocarbon dates (A.D. 1469-1614) from the site indicate that the later occupation at the site is contemporaneous with the Late Caddo period in the Red River (Lynott 1975a).
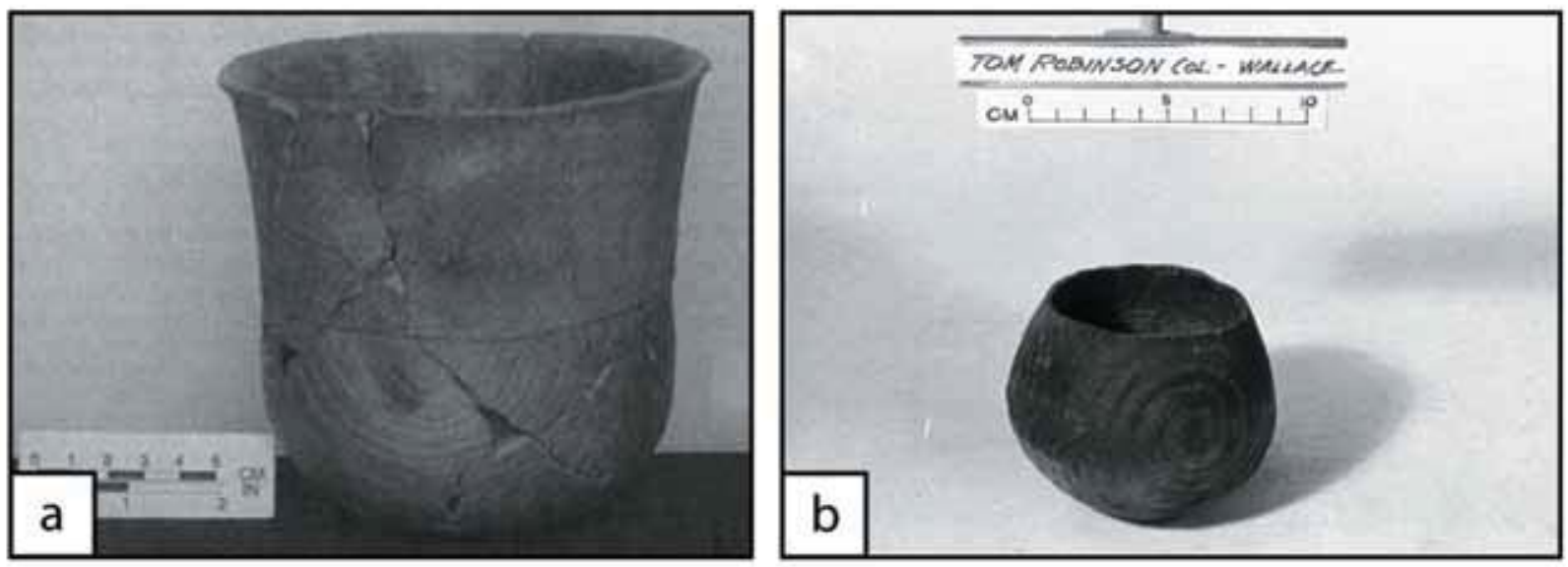

Figure 10. Outlier vessels containing Foster Trailed-Incised characteristics. (a) Sister Grove Creek site (41COL36) (Crook and Perttula 2008) (b) Wallace site (3AR25) (AAS Neg. \#714964). 


\section{Wallace (3AR25)}

The Wallace site is a mound and village site located in Arkansas County, Arkansas on the west bank of Locust Bayou, a former active Arkansas River channel. The vessel found there is globular in form and the rim is missing (Figure 10b). From the image alone, it is impossible to discern if the missing rim is deliberate or has been broken. The body resembles Foster Trailed-Incised vessels with a series of concentric circles. A centralized node is present but it is difficult to determine from the image if it is appliquéd.

\section{Glendora site (160U32) and Keno site (16MO31)}

The Glendora and Keno sites are located along Bayou Bartholomew in northeast Louisiana (Kidder 1988). The Glendora site is located near the confluence of Bayou Bartholomew and the Ouachita River. A large assemblage of Late to Historic Caddo ceramic types from the Glendora site is identified as types found in the Lower Ouachita Basin (Kidder 1988:368-371). The ceramic assemblage at the Keno site is similar to that discovered at Glendora in that it contained Late and Historic Caddo ceramic types.

At Glendora and Keno, Kidder (1988:Figure 51) classifies three vessels as being Foster Trailed-Incised (Figure 11). A vessel from the Keno site is assigned to var. Finley (Figure 11i), a single vessel from the Glendora site is assigned to var. Shaw (not pictured), and two additional vessels from the Glendora site are assigned as var. unspecified (Figure 11g-h).

One of the vessels from Glendora (Figure 11g) most resembles the form and design of Foster TrailedIncised vessels located in the Ouachita River drainage. It contains a series of concentric circles with appliqué nodes on the vessel body. The primary rim design consists of rows of punctates with two incised lines above the rim-body juncture. The identification of var. Finley and var. Shaw at the Glendora and Keno sites suggests contact with Late Caddo groups along the Red River in southwest Arkansas (see Schambach and Miller 1984:121). Additionally, similarities in form and design (see Figure 11g) to vessels in the Ouachita River drainage suggest contact with Caddo groups to the north along the Ouachita River, possibly associated with interregional salt trading networks (see Early 1993b). Interestingly, one of the vessels from Glendora (see Figure 11h), classified as var. unspecified, resembles in form and design specific vessels from the Joe Little site, the Lymon Moore site (34LF31) and the Los Adaes site (16NA16) that have already been mentioned.

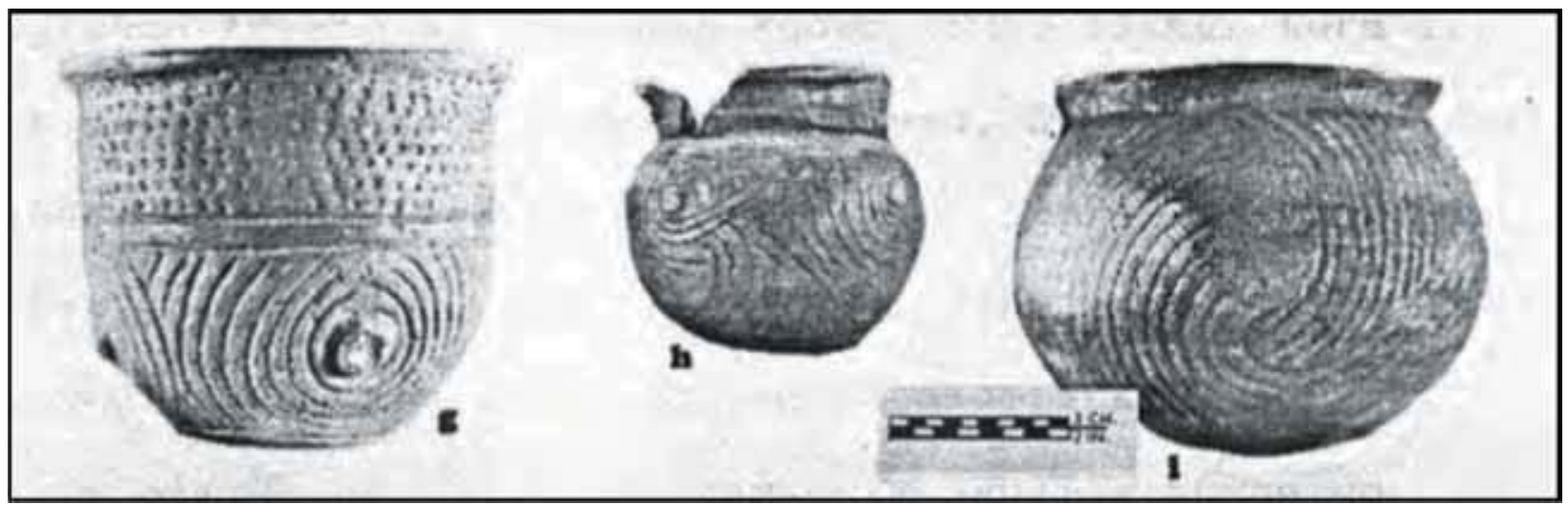

Figure 11. Foster Trailed-Incised vessels from Glendora (160U32) and Keno (16M031) sites. (g) var. unspecified, (h) var. unspecified, (i) var. Finley (Kidder 1988). 


\section{Conclusions and Directions}

A Geographic Information System (GIS) is an informative visual tool for demonstrating patterns of spatial distributions. The preliminary distribution analysis presented in this article exemplifies some of the difficulties inherent with ceramic typologies when viewed across space, but also demonstrates the efficacy of a spatial analysis in order to begin to understand cultural relationships. The seven outlier sites and their corresponding ceramic vessels all reveal characteristics and similarities to emblematic Foster Trailed-Incised vessels located in the Red and Ouachita River valleys.

A single Foster Trailed-Incised vessel from the Joe Little site (see Figure 9a), most resembles Late Caddo var. Moore or var. Shaw, but does contain differences in body incised scrolling designs. A single vessel from the Henry Williams site (see Figure 9b) contains concentric circles on the body, similar in design to Foster TrailedIncised, although the treatment is with pinched rather than incised lines. A single vessel from the Langford site (see Figure 9c) resembles a Foster Trailed-Incised vessel based on form and overall design but is unlike those located at sites within the Red River valley or the Ouachita valley. It has been considered as a possible earlier variety of Foster Trailed-Incised or a different local type, such as Washington Square Paneled (Hart 1982). A single vessel from the Sister Grove Creek site (see Figure 10a) represents the first known occurrence of this vessel type along the East Fork of the Trinity River (Crook and Perttula 2008) and implies long distance trade with groups along the Red River in southwestern Arkansas. A vessel from the Wallace site (see Figure 10b) resembles Foster Trailed-Incised vessels with a series of concentric circles and a centralized node. The Foster Trailed-Incised vessels from the Glendora site (see Figure 11) resemble Late Caddo Foster Trailed-Incised vessels found in the Red River and Ouachita River valleys suggesting contact with Caddo groups throughout southwest Arkansas and possibly farther afield.

Future directions for this analysis are primarily focused around achieving a higher resolution of data attributes (such as temper, form, and treatment), acquiring additional examples of Foster Trailed-Incised vessels, adding ecological and geological data, and the inclusion of other Caddo ceramic types.

Higher resolution can be achieved by further identification of temper used, and by the development of additional categories of form and treatment, such as those used in the Collegiate Classification System (see Early 1988, 1993a; Kelley 1997; Schambach 1981; Schambach and Miller 1984). Additional examples of Foster Trailed-Incised vessels will help with statistical analyses, while the inclusion of ecological and geological datasets will allow for the exploration of correlates between environment and vessel attributes. Lastly, the inclusion of additional Caddo pottery types with similar formal and decorative characteristics to those that define the Foster Trailed-Incised type will allow for overlaps between ceramic types to be realized spatially and statistically and relationships between cultural groups to be explored.

\section{Acknowledgements}

Many thanks to the contribution of many individuals, including Dr. Ann Early, her students and employees from Henderson State University, including (the now) Drs. Mary Kay Sandford and David B. Kelley, Arkansas Archeological Survey photographer Dan Printup, University of Arkansas Museum photographer Mary McGimsey, Dr. Frank Schambach, and many others for taking all the photographs of vessels that became the "analog database", compiled and organized by Dr. Schambach during his tenure in Magnolia, Arkansas. Having much of the ceramic data easily accessible allowed for the fairly seamless (although time consuming) compiling of the "digital database". Many thanks go to several individuals who referred me to literature and reports, 
including Drs. Jamie Brandon, Ann Early, John House, Tom Middlebrook, Tim Perttula, George Sabo III, and Frank Schambach. Drs. Early, Perttula, Sabo, and Schambach all read earlier versions of this article and provided valuable comments and suggestions related to both content and future directions. Lela Donat, registrar at the Arkansas Archeological Survey, was especially helpful in locating Arkansas related documents and photos. Mark Walters provided much help with identifying sites in east Texas. As always, thanks to the Caddo people for allowing others to learn and explore their cultural heritage. An original version of this article was presented at the $52^{\text {nd }}$ Caddo Archeological Conference held in Tyler, Texas.

\section{References Cited}

Brown, James A.

1996 The Spiro Ceremonial Center: The Archaeology of Arkansas Valley Caddoan Culture in Eastern Oklahoma. Memoirs of the Museum of Anthropology, University of Michigan, No. 29. Ann Arbor: Museum of Anthropology, University of Michigan.

Crook, Wilson W., III, and Timothy K. Perttula

2008 A Foster Trailed-Incised Vessel from the Sister Grove Creek Site (41COL36), Collin County, Texas. Caddo Archeology Journal 18:22-25.

Early, Ann M.

1988 Ceramics. In Standridge: Caddoan Settlement in a Mountain Environment, by Ann M. Early, pp. 61104. Arkansas Archeological Survey Research Series 29, Fayetteville.

1993a Ceramics. In Caddoan Saltmakers in the Ouachita Valley: The Hardman Site, edited by Ann M. Early, pp. 63-118. Arkansas Archeological Survey Research Series 43, Fayetteville.

1993b Hardman and Caddoan Saltmaking. In Caddoan Saltmakers in the Ouachita Valley. pp. 223-234. Arkansas Archeological Survey Research Series 43. Fayetteville.

Gregory, Hiram F.

1973 Eighteenth-Century Caddoan Archaeology: A Study in Models and Interpretation. Southern Methodist University, Ph.D, Anthropology. Ann Arbor, University Microfilms.

Hart, John P.

1982 An Analysis of the Aboriginal Ceramics from the Washington Square Mound Site, Nacogdoches County, Texas. Master's Thesis, Department of Anthropology, Northeast Louisiana University, Monroe.

Hemmings, E. Thomas

1982 Spirit Lake (3LA83): Test Excavations in a Late Caddo Site on the Red River. In Contributions to the Archeology of the Great Bend Region, edited by Frank F. Schambach and Frank Rackerby, pp. 55-89. Research Series 22, Arkansas Archeological Survey, Fayetteville.

House, John $\mathrm{H}$.

1991 The Mississippian Sequence in the Menard Locality, Eastern Arkansas. In Arkansas before the Americans, edited by Hester A. Davis, pp. 6-39. Arkansas Archeological Survey Research Series 40, Fayetteville. 


\section{References Cited (cont.)}

Jackson, A.T., Marcus S. Goldstein, and Alex D. Krieger

2000 The 1931 Excavations at the Sanders Site Lamar County, Texas. Archival Series 2, Texas Archeological Research Laboratory, University of Texas.

Kelley, David B.

1997 Ceramic Analysis. In Two Caddoan Farmsteads in the Red River Valley: The Archeology of the McLelland and Joe Clark sites, edited by David B. Kelley, pp. 37-60. Arkansas Archeological Survey Research Series 51. Fayetteville.

Kelley, David B. and Carey L. Cox

1998 Cultural Resources Survey of Levee Rehabilitation/Restoration Areas Along the Red River Between Fulton, Arkansas and the Louisiana State Line: Items 4, 5, and 9. Report submitted by Coastal Environments, Inc., to the U.S. Army Corps of Engineers, Vicksburg, Mississippi.

Kidder, Tristram R.

1988 Protohistoric and Early Historic Culture Dynamics in Southeast Arkansas and Northeast Louisiana A.D. 1542-1730. Ph.D. Dissertation, Department of Anthropology, Harvard University.

Krieger, Alex D.

1946 Culture Complexes and Chronology in Northern Texas, with Extensions of Puebloan Dating to the Mississippi Valley. Publication No. 4640. The University of Texas, Austin.

Lynott, Mark J.

1975a Archeological Investigations at Lake Lavon, 1974. Contributions in Anthropology 16. Archaeology Research Program, Southern Methodist University, Dallas.

1975b Wylie Focus Pits in Light of Recent Investigations. The Record, Dallas Archeological Society, Vol. 31, No. 2, pp. 1-4.

Moore, Clarence B.

1912 Some Aboriginal Sites on the Red River. Journal of Academy of Natural Sciences of Philadelphia 14:481-638.

Moorehead, Warren K.

1931 The Archaeology of the Arkansas River Valley. Andover Press, Andover, Massachusetts.

Perino, Gregory

1994 Archaeological Research at the Rowland Clark Site (41RR77), Red River County, Texas. Journal of Northeast Texas Archaeology 4:3-42.

1995 The Dan Holdeman Site (41RR11), Red River County, Texas. Journal of Northeast Texas Archaeology 6:3-65.

Perttula, Timothy K.

2005 1938-1939 WPA Excavations at the Hatchel Site (41BW3) on the Red River in Bowie, County, Texas. Southeastern Archaeology 24: 180-198.

2006 A Study of the Buddy Calvin Jones Collection from Northeast Texas Caddo Sites. Friends of Northeast Texas Archaeology. Special Publication No. 6, Austin and Pittsburg. 


\section{References Cited (cont.)}

Perttula, Timothy K., Bo Nelson, Mark Walters, Robert Cast, and Bobby Gonzalez

2009a Documentation of Caddo Funerary Objects in the Gilcrease Museum Collections. Special Publication No. 12. Friends of Northeast Texas Archaeology, Austin and Pittsburg.

Perttula, Timothy K., Robert Cast, Bobby Gonzalez, and Bo Nelson

2009b Documentation of Unassociated and Culturally Unidentifiable Funerary Objects In the U.S. Army Corps of Engineers, Fort Worth District Collection Housed at the Texas Archeological Research Laboratory at the University of Texas at Austin. Friends of Northeast Texas Archaeology. Special Publication No. 13.

Perttula, Timothy K., Mark Walters, Shawn Marceaux, and Bo Nelson

2009c Caddo Pottery Vessels and Pipes From Sites in the Middle and Upper Neches River Basins, Smith and Wood Counties. Friends of Northeast Texas Archaeology. Special Publication No. 7, Austin and Pittsburg.

Perttula, Timothy K., Mark Walters, and Bo Nelson

2009d Documentation of the Native American Ceramic Vessels from Northeast Texas, Southern Arkansas, and Eastern Oklahoma in the Boyce Smith Museum in Troup, Texas. Friends of Northeast Texas Archaeology. Special Publication No. 8.

Perttula, Timothy K., and Bo Nelson

2009 Prehistoric Artifact Assemblages from Sites along Hickory Creek in the Davy Crockett National Forest, Houston, County, Texas. Friends of Northeast Texas Archaeology. Special Publication No. 14.

Rohbaugh, Charles L.

1982 Spiro and Fort Coffee Phases: Changing Cultural Complexes of the Caddoan Area. Ph.D. Dissertation, The University of Wisconsin-Madison.

Schambach, Frank F.

1981 A Description and Analysis of the Ceramics. In The Shallow Lake Site (3UN9/52) and its Place in Regional History, edited by W. Frederick Limp, pp. 101-176. Research Series 12. Arkansas Archeological Survey, Fayetteville.

Schambach, Frank F. and John E. Miller

1984 A Description and Analysis of the Ceramics. In Cedar Grove: An Interdisciplinary Investigation of a Late Caddo Farmstead in the Red River Valley, edited by W. Frederick Limp, pp. 109-170. Research Series 23. Arkansas Archeological Survey, Fayetteville.

Schambach, Frank F., Neal L. Trubowitz, Frank Rackerby, E. Thomas Hemmings, W. Frederick Limp, and John E. Miller III

1982 Test Excavations at the Cedar Grove Site (3LA97): A Late Caddo Farmstead in the Great Bend Region. In Contributions to the Archeology of the Great Bend Region, edited by Frank F. Schambach and Frank Rackerby, pp. 90-130. Research Series 22, Arkansas Archeological Survey, Fayetteville. 


\section{References Cited (cont.)}

Suhm Dee Ann and Edward B Jelks (editors)

1962 Handbook of Texas Archeology: Type Descriptions. The Texas Archeological Society Special Publication No. 1 and Bulletin No. 4, The Texas Memorial Museum, Austin.

Suhm, Dee Ann, Alex D. Krieger, and Edward B. Jelks

1954 An Introductory Handbook of Texas Archeology. Bulletin of the Texas Archeological Society 25:1562.

Sundermeyer, Scott A., John T. Penman, and Timothy K. Perttula

2008 Integrated Cultural Resources Investigations for the Bowie County Levee Realignment Project, Bowie County, Texas and Little River County, Arkansas. Miscellaneous Reports, Report of Investigations No. 29. Lopez Garcia Group, Dallas.

Trubowitz, Neal L., Frank F. Schambach, and John E. Miller III

1982 Test Excavations at 3LA128: An Early Caddo Occupation on the Red River. In Contributions to the Archeology of the Great Bend Region, edited by Frank F. Schambach and Frank Rackerby, pp. 39-54. Research Series 22, Arkansas Archeological Survey, Fayetteville.

Walters, Mark

1997 The Langford Site (41SM197), Smith County, Texas. Journal of Northeast Texas Archaeology 9:3841.

Webb, Clarence H.

1959 The Belcher Mound: A Stratified Caddoan Site in Caddo Parish, Louisiana. Memoir 16. Society for American Archaeology, Salt Lake City.

Webb, Clarence H. and Monroe Dodd, Jr.

1941 Pottery Types from the Belcher Mound Site. Bulletin of the Texas Archeological and Paleontological Society 13:88-116.

Weinstein, R.A., David B. Kelley, and Joe W. Saunders (editors)

2003 The Louisiana and Arkansas Expeditions of Clarence Bloomfield Moore. University of Alabama Press, Tuscaloosa.

Wheatley, David and Mark Gillings

2002 Spatial Technology and Archaeology: The Archaeological Applications of GIS. Taylor and Francis, London. 